\title{
ПРИНЦИПЫ СИСТЕМАТИЗАЦИИ ЛЕКСИКИ В ИДЕОГРАФИЧЕСКОМ СЛОВАРЕ
}

Лексикографические изыскания тесно связаны с проблемой отражения изменений в фактическом материале. Идеографический словарь как словарь активного типа является спеичфическим объектом изучения и выступает одновременно как метод исследования лексической системы языка в иелом. Идеографическое описание лексики представляет в своей совокупности модель языковой картины мира.
Ключевые
слова:
лексикография, идеографический словарь, когнитивная лингвистика, кониепт, макроконцепт, функиионально-когнитивная сфера.

Lexicographic research is closely related to the live facts. The thesaurus is a specific object of study and acts simultaneously as a research tool for the lexical system. The ideographic description of the language is a model of the linguistic worldview.

Key words: lexicography, thesaurus, cognitive linguistics, concept, macroconcept, functional-cognitive sphere.

Разработка словарей активного типа в настоящее время остается актуальной задачей лексикографии. Новые направления в обучении языкам и в развитии лингвистики дают основания для поисков в практике создания словарей, которые, по сути, являются учебно-функциональными. Словарь активного типа оказывает серьезную помощь преподавателям в формировании способности к межкультурной коммуникации в процессе изучения языков, т.к. способствует усвоению языковой и 
внеязыковой информации, формированию у учащихся коммуникативно-познавательных потребностей.

Рассмотрим концепцию создания одного из словарей серии учебных словарей, изданных под руководством д.ф.н., проф. Кильдибековой Т.А., - Функционально-когнитивный словарь русского языка. Языковая картина мира. Первые словари данной серии, изданные ещё в конце девяностых годов, послужили источником отбора словарного материала и сочетаемости слов при составлении учебных словарей, учебников для русских и нерусских учащихся и стали основой создания двуязычных словарей лексических соответствий (русско-английского, русскофранцузского).

Предлагаемый к рассмотрению проект создания словарей разработан на основе функционально-когнитивного подхода к систематизации словарного материала среднего носителя русского языка, что в значительной мере отражает его картину мира, а также природу развития и организации естественного языка.

Впервые выявлена и описана крупнейшая системообразующая единица языка, называемая функциональнокогнитивной сферой (ФКС), которая выступает в качестве композиционной единицы словаря. ФКС - это многомерное образование, которое позволяет выделить наиболее объемный фрагмент языка. Сфера базируется на глобальном понятии макроконцепте, который предполагает различные семантические аспекты развертывания общего смысла. Сложная структура словарного состава показана с учетом антропоцентричности языка, выступающей как принцип его описания, дающий возможность представить в новом ракурсе словарный состав, преломив его через призму восприятия и жизнедеятельности человека [Гафарова, Кильдибекова 2003: 115].

Функциональный подход является ключевым в систематизации лексического материала. Она лежит в основе организации всей лексики, уровней ее иерархии и предполагает представление в словаре речеобразующих свойств языковых единиц, которые выражаются в их комбинированных свойствах.

Когнитивный подход основан на базовой категории семантики - понятии, реализующем ментальные сущности разного объема и выступающем в качестве основной единицы 
обработки, хранения и передачи знаний, - концепте. Концепты предопределяют все приемлемые употребления этой языковой единицы носителями языка и представляют собой характерные для данного языка «стереотипы» сознания, набор которых определяет членение лексического состава языка [Кубрякова 1995: 195]. Концепты реализуются в единицах языка - лексемах, фразеологизмах и сочетаниях слов. В словаре представлена одна из попыток построения модели концептуального анализа, концептуальных сетей русского языка [Функциональнокогнитивный словарь русского языка. Языковая картина мира 2013].

Для составления словаря принципиальное значение имеет выделение глобальных понятий - макроконцептов, обладающих большим систематизирующим потенциалом и организующим вокруг себя обширные разряды слов.

Отбор макроконцептов и лексического материала для представления в словаре проведен по их функциональной значимости. В словаре даны актуальные макроконцепты, которые обозначают, во-первых, главные сферы жизнедеятельности человека и восприятия им окружающего мира, что, во-вторых, отражает и речемыслительную деятельность человека. Весь лексический материал представлен в шести функциональнокогнитивных сферах: 1) Жизнь человека; 2) Движение; 3) Восприятие окружающего мира; 4) Речемыслительная деятельность и образование; 5) Деятельность; 6) Человек в языке. Они покрывают основные аспекты жизнедеятельности человека и играют главную роль в познании мира и практике общения. При формировании словника учитывается функциональнокогнитивная ценность слова, предполагающая набор его смысловых (концептуальных) связей, т.е. потенциал лексемы в полном объеме.

Сферы разнотипны по своей структуре и наполнению, это обусловливает разный подход к их описанию и представлению в словаре. Структурная организация сферы предопределена объемом содержания макроконцепта, его функциональной ориентированностью на определенные «участки» устройства мира и восприятия человека, а также частеречным и лексическим выражением и количеством парадигматических групп. Общим для них является многоступенчатый иерархический характер 
связей входящих в них единиц. Перечисленные функциональнокогнитивные сферы делятся на несколько уровней иерархии, которые характеризуют вертикальную и горизонтальную упорядоченность лексики. Следование разделов определяется по степени удаленности от общего понятия (макроконцепта). Каждый класс слов конкретизирует определенный аспект его содержания и имеет свои заголовочные слова.

В словаре шесть глобальных ФКС распределены по 25 разделам, 120 подразделам, 238 классам, 347 подклассам, 4152 лексическим группам. Каждая сфера различается по объему материала и количественным показателям. Семантические отношения в каждой группе предопределяются ключевым (заголовочным) словом, силой притяжения по вертикали и горизонтали, его линейными и объемными проявлениями. Чем более разнообразны семантические связи слова, тем выше его ценность.

В структурной организации лексических групп, кроме традиционно выделяемых межчастеречных, родовидовых, синонимических, антонимических, ассоциативных, словообразовательных отношений, представлены также следующие типы глубинных связей: концептуальная хронология - порядок следования семантических процессов: родиться жить - умереть; концептуальная деривация - отношение смысловой производности между событиями и их участниками: работать - работник, место работы, орудие, результат; расщепление концепта в синхронных понятиях, выступающих на одном уровне концептуальных отношений: жители - земляне, европейщьы, австрийцы, горожане, жильцы дома.

Особенно активны словообразовательные связи. Наиболее частотны отглагольные словообразовательные пары. В них выступают такие типы производных, как абстрактные существительные (выпускать продукиию - выпуск продукиии), наименования лиц (жить - житель), обозначения места (жить жилище), передача признака (жить -жилой). В глаголах широко представлены словообразовательные парадигмы (строить построить, выстроит и т.д.)) и словообразовательные гнезда .

В словаре продемонстрирована возможность последовательного членения лексической системы языка путем выделения разноуровневых ступенчатых объединений лексем, 
отражающих основные закономерности ее строения целостность, непрерывность, иерархичность и встроенность одних групп в другие.

Перечисленные функционально-когнитивные сферы делятся на несколько уровней иерархии, которые характеризуют вертикальную и горизонтальную упорядоченность лексики. Следование разделов определяется по степени удаленности от общего понятия (макроконцепта). Каждый класс слов конкретизирует определенный аспект его содержания и имеет свои заголовочные слова.

На первом уровне иерархии выделяются объемные лексические разряды, содержание которых отражает главные направления развертывания макроконцепта. Например, в сфере «Жизнь человека» представлены: Место жительства; Семья. Родственные отношения; Качество жизни и т.д. Эти перечисления расположены «веерообразно» по отношению к базовому понятию и показывают его горизонтальный «срез».

Второй уровень иерархии составляют подразряды, которые характеризуют дальнейшую конкретизацию первого уровня; например, в разделе «Место жительства» выделяются последовательно, ступенчато подразделы: Земля. Континенты. Страны. Населенные пункты и т.д. Они реализуют вертикальный «срез» подраздела.

Третий уровень иерархии включает прототипические обозначения реалий предыдущего уровня: «Населенные пункты» - город, деревня, временное поселение. На периферии группы даются второстепенные лексемы.

На четвертом уровне, наиболее удаленном от общего понятия, представлены обозначения дополнительных реалий: «Город», «Деревня» - части населенного пункта, изменение места проживания.

На пятом уровне выступают лексические группы, состоящие из заголовочного слова с включением его функциональных признаков. Объем групп и их количественный состав обусловлен информационной ценностью лексемы

Особую роль в организации семантических групп играют ключевые слова - глаголы и имена существительные жить жизнь, думать - мыслли и т.д. 
В словарь на каждом уровне подачи материала в большом количестве включаются синтагматические характеристики заголовочных слов, играющих главную роль в порождении высказывания; даются наиболее употребительные типы сочетаний лексем.

Словарный материал размещается по частеречным группам. Составные наименования как устойчивые лексикализованные сочетания даются отдельно (детский дом). Значительный перечень прилагательных вводится только для ключевых слов, играющих главную роль в группе.

Далее описываются словосочетания существительных с существительными - беспредложные и предложные.

Особо рассматриваются сочетания существительного с глаголами, в которых выражаются многочисленные ситуации, включающие заголовочное существительное: власть - получить, завоевать и т.д.; бороться за власть; стремиться, рваться к власти $u$ m.д. Далее в блоке приводятся функциональные модификации исходного слова: собирательные - единичные имена, оценочные производные слова (деньги - деньжата $u$ m.д.); синонимические параллели (деньги, финансы и т.д.)); антонимические пары (жара - холод). В конце блока помещаются прилагательные, образованные от ключевого слова со своими наборами предметных имен, которые характеризуют сферы функционирования реалий (дети - детский манеж, игрушка и m.д.).

Словарные блоки с глаголами ориентированы на событийность, ситуативность. С максимальной полнотой отражаются наборы ситуаций, которые связаны с базовыми глаголами, имеющими широкое значение и выступающими в качестве слова-доминанты ФКС: жить, двигаться, говорить, paботать, видеть, сльишать. Валентность каждого глагола предопределяет синоптическую схему всей сферы: жить - где (место жительства); жить - с кем (семья и родственные отношения); жить - на что (материальное положение); жить - как (качество жизни) и т.д.

Далее представлен набор лексико-грамматических характеристик глагола: фазы действия, каузативность, пассив, однократность. 
Выделяются информационно-смысловые комплексы со значением объекта, места, времени, результата. Далее вводятся синонимы (работать, вкальввать и т.д.), антонимы (трудиться бездельничать). Последние чаще всего выражаются отрицательной частицей не (видеть - не видеть). Они, как правило, не представлены в других типах словарей, несмотря на их частотность в речевой практике.

Схема анализа прототипических глаголов выдерживается в блоках всех уровней.

Прилагательные чаще всего выступают в зависимой позиции при существительных. В словарь включаются лексемы, обозначающие интенсивность признака (большой, больщущзий), синонимы (большой, громадный)), антонимы (большой небольшой, маленький и т.д). Нередко они образуют смысловые цепочки.

В словаре дана минимальная информация о грамматических свойствах лексических единиц. Отмечается исходная форма существительного - именительный падеж единственного числа. Форма множественного числа указывается, когда необходимо дифференцировать области употребления слов: работа тяжелая, физическая, умственная; работь - строительные, ремонтные, монтажные и т.д. Множественное число приводится с учетом активности словоупотребления: народ - нapodbl, беженец - беженцы, а также для обозначения родового понятия (животные, звуки, привычки).

Существительные, обозначающие лицо, даются в основном в исходной форме мужского рода. Соответствующее им образование женского рода приводится в случаях, когда данная форма строится не по типичной словообразовательной модели: актер - актриса, поэт - поэтесса, бомж - бомжиха.

Глаголы указываются в неопределенной форме, несовершенного вида. Видовые пары не всегда представлены. В качестве основной формы могут выступать глаголы и несовершенного, и совершенного вида, пометы для характеристики видов не используются. При необходимости приводятся личные формы: лаять - собака лает.

Прилагательные даны в полной форме, краткие формы приводятся редко. 
Стилистические пометы используются в ограниченном количестве. Подавляющее большинство слов относится к нейтральной лексике. Стилистические маркировки указывают на сферу применения, включая стили литературного языка: книжн., высок., нар. - поэт. и т.д. Хронологические пометы устар., cmap., истор., нов. В словаре не используется помета прост.; отмечается сниженная речь (сниж.) с ее вариациями груб., вульг., жарг. и др.

Данный словарь отражает словарный запас среднего носителя русского языка и предназначен широкому кругу русскоговорящих, всем, кто интересуется русским языком, а также студентам, аспирантам, докторантам при написании курсовых, дипломных и диссертационных работ. Полезен словарь и для лиц, изучающих русский язык как иностранный на разных уровнях овладения. Словарь содержит обширную базу данных для разноаспектных теоретических изысканий.

\section{ЛИТЕРАТУРА}

1. Гафарова Г.В., Кильдибекова Т.А. Теоретические основы и принципы составления функциональнокогнитивного словаря. - Уфа, РИО БашГУ, 2003. $301 \mathrm{c}$.

2. Кубрякова Е.С. Эволюция лингвистических идей во второй половине XX века (опыт парадигмального анализа) // Язык и наука конца XX века. - M., 1995.

3. Функционально-когнитивный словарь русского языка. Языковая картина мира / Под общим руководством Т.А.Кильдибековой - СПб., 2011 ; М. «Гнозис», 2013. - 670 с.

(C) Гафарова Г.В., 2021 г. 